\title{
Anatomy and shell shape variability in a land snail Bostryx torallyi (Stylommatophora: Bulimulidae)
}

\section{María José Miranda ${ }^{1}$}

1. Facultad de Ciencias Naturales e IML, Universidad Nacional de Tucumán-Instituto de Biodiversidad Neotropical, CONICET-UNT, Miguel Lillo 205, C.P., 4000 San Miguel de Tucumán, Argentina; mirandamjo@hotmail.com

\author{
Received 27-V-2019. Corrected 25-XI-2019. Accepted 23-II-2020.
}

\begin{abstract}
Introduction: The gastropod Bostryx torallyi shows high variability in shell shape and coloration. Subspecies of this organism have been described based on shell characters but, since they were slightly different, they were synonymized afterwards. Until now, shell variability has been analyzed only descriptively and its anatomy is still unknown. Objective: In this study, I provide anatomical information of $B$. torallyi and apply a geometric morphometric analysis to evaluate the shell shape variation among specimens. Methods: To accomplish this, type material and numerous lots were examined and dissected out. Additionally, relative warp analysis, based on 9 landmarks in ventral view of the shell, was performed using 80 specimens of 9 localities from Bolivia and Argentina. Results: According to our results, geometric morphometrics is a suitable method to evaluate differences in shell shape among localities; for instance, distinctions in the shell were noticeable between gastropods of low and high altitudes. On the other hand, it was established that the coloration of this species is independent of large-scale factors since the examined specimens came from environments with similar conditions. Furthermore, the sculpture of the protoconch and anatomy of B. torallyi coincided with the other Argentinian species of the genus. Conclusions: Therefore, I concluded that a geometric morphometric analysis of shell shape is a good complement to traditional qualitative description of the characteristics of the shell in this species.
\end{abstract}

Key words: altitude, intraspecific variability, geometric morphometric, relative warp, Argentina, Bolivia.

Miranda, M. J. (2020). Anatomy and shell shape variability in a land snail Bostryx torallyi (Stylommatophora: Bulimulidae). Revista de Biología Tropical, 68(1), 218-229.

The gastropod Bostryx torallyi (d'Orbigny, 1835) has been recorded in Argentina, Bolivia, Paraguay and Peru (Quintana, 1982; Zischka, 1953; Miquel, 1995; Ramírez, Paredes, \& Arenas, 2003; Cuezzo, Miranda, \& Ovando, 2013). It is recognized by its fusiform shell shape and presence of strong color bands. Nonetheless, there is a great intraspecific variability in shell characters, such as a spire and body whorl shape, a teleoconch sculpture and coloration pattern in certain organisms.

Parodiz (1947) tried to explain the variation in shell characters by describing varieties like Bostryx torallyi avus, B. torallyi corrugatus and $B$. torallyi nigroumbilicatus and classify Bulimus draparnaudi Pfeiffer, 1846 as a subspecies whose morphological boundaries were poorly differentiated. Afterwards, Miquel (1995) synonymized all Parodiz's subspecies and varieties, considering them as variations of B. torallyi. In addition, Miquel (1995) also synonymized species with similar shell shape and coloration patterns such as Bulimulus montagnei d'Orbigny, 1837, Bulimulus (Mesembrinus) climacographus Holmberg, 1912 and Peronaeus (Lissoacme) birabeni Hylton Scott, 
1948. Currently, this taxonomical classification has been widely accepted; for instance, Cuezzo et al. (2013) still use it.

Like in most gastropods, taxonomy of $B$. torallyi has traditionally been based on shell morphology. The variability of its shell has only been analyzed descriptively with some linear measurements (Miquel, 1995). Consequently, morphological variations remain unclear. Currently, geometric morphometrics have proved to be useful and have been widely utilized in gastropod studies to evaluate the variation in shell morphology (Carvajal Rodríguez, CondePadin, \& Rolan-Álvarez, 2005; Márquez \& van der Molen, 2011; Miranda \& Cuezzo, 2014). Furthermore, in land snails, phenotypic variability of shell traits within and among populations of geographically subdivided taxa haven widely studied (Pfenninger \& Magnin, 2001).

While the combined effects of genetic differentiation and phenotypic plasticity can determine shell morphology, some authors have suggested that an important proportion of the variance in shell morphology is a direct response to environmental factors (Smith \& Hendricks, 2013; Dillon \& Jacquemin, 2015). The possible influence of the environment on the shell shape variability of $B$. torallyi has not yet been examined. Therefore, the objectives of the present study were to: (1) provide detailed anatomical information of Bostryx torallyi, (2) apply the geometric morphometric analysis to evaluate shell shape variation among specimens from localities in Bolivia and Argentina.

\section{MATERIALS AND METHODS}

Location: The dry shells and specimens conserved in alcohol studied come from collections of the Instituto-Fundación Miguel Lillo (IFML-Moll) in Tucumán, the Museo Argentino de Ciencias Naturales "Bernardino Rivadavia" (MACN-In) in Buenos Aires and the Museo de La Plata (MLP) in La Plata. Additionally, specimens of Bostryx torallyi were collected from northern $\left(22^{\circ} \mathrm{S}\right)$ to central Argentina $\left(27^{\circ} \mathrm{S}\right)$ during summer-autumn seasons with a sampling effort standardized for time through manual collecting.

Anatomical analysis: Living organisms were drowned in deoxygenated water, fixed in $96 \%$ ethanol, and later transferred and preserved in $80 \%$ ethanol. The radula and jaw were extracted and prepared according to Ploeger \& Breure (1977). Afterwards, they were photographed with a Jeol Scanning Electron Microscope 35CF at the Research Center and Services of Electron Microscopy (CISME). Other anatomical systems were dissected out from ten alcohol fixed specimens from different localities. Those structure were drawn with the aid of a camera lucida under a Leica MZ6 microscope.

Geometric morphometric analysis: Photographs of the adult shells from a ventral view were taken using a Nikon D5000 digital camera mounted on a fixed tripod. These images were converted to a TPS format with the TpsUtil v. 1.78 program (Rohlf, 2019) and landmarks (LM) were digitalised with the

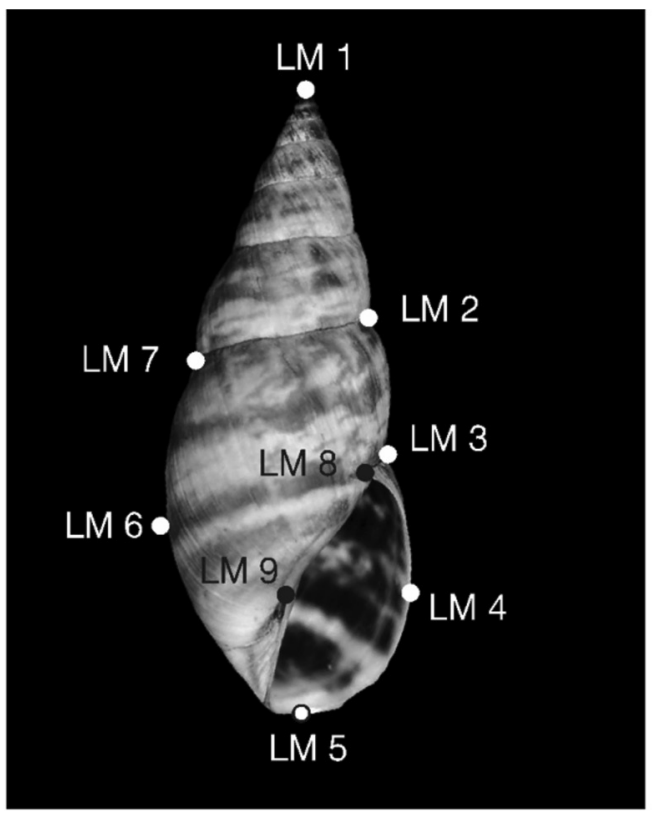

Fig. 1. Ventral view of the shell's nine landmarks.

Fig. 1. Localización de los nueve "landmarks" en vista ventral de la concha. 


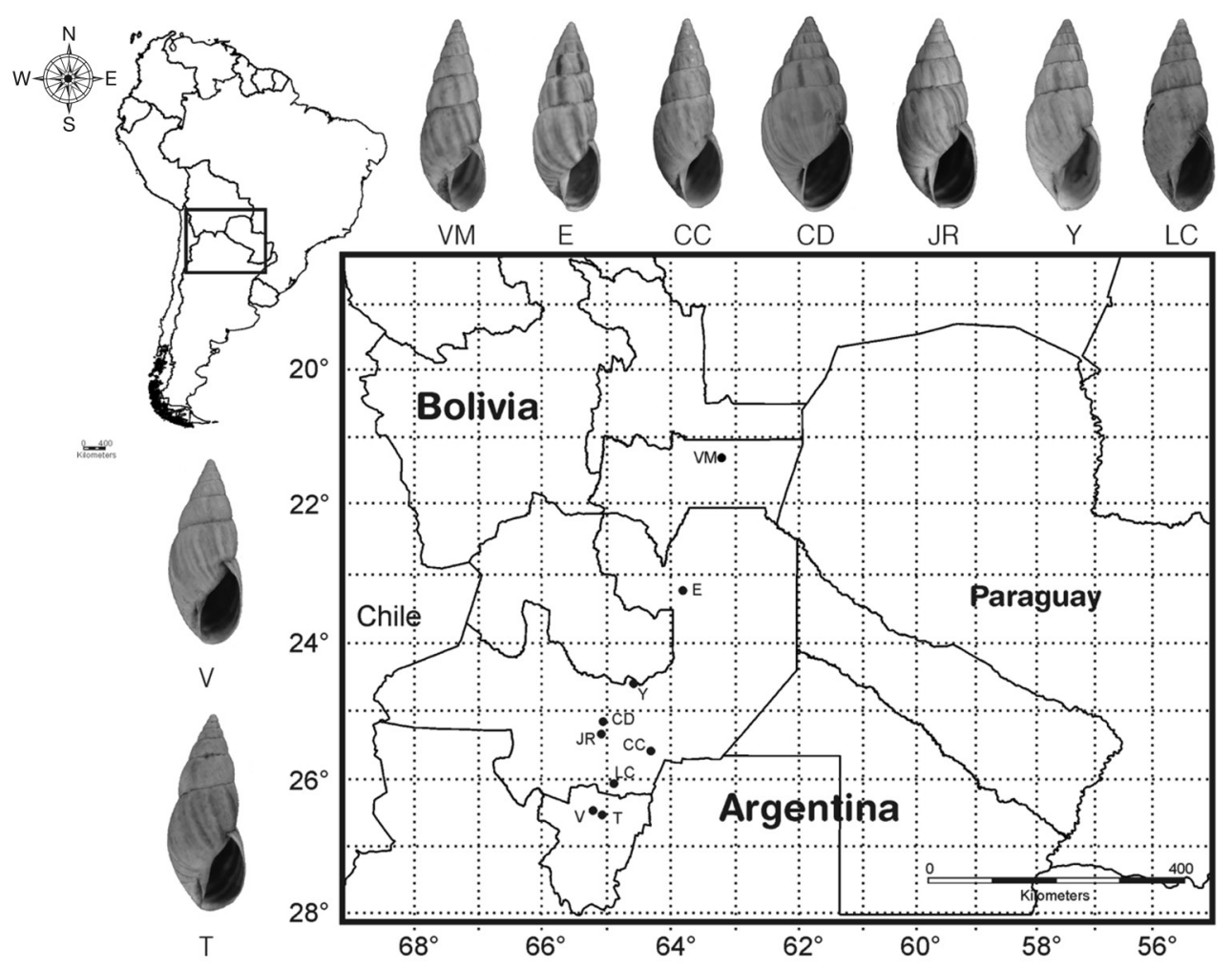

Fig. 2. Distribution map of localities considered in the morphometric analysis and shell shape morphology in each locality. Abbreviations: CC: Cerro Colorado, CD: Cabra Corral dam, E: Embarcación, JR: Juramento River, LC: La Candelaria, T: Ticucho, V: Vipos, VM: Villa Montes, Y: Yaquiasme.

Fig. 2. Mapa de distribución de las localidades consideradas en el análisis morfométrico y morfología de las conchas de cada localidad. Abreviaturas: CC: Cerro Colorado, CD: Represa Cabra Corral, E: Embarcación, JR: Río Juramento, LC: La Candelaria, T: Ticucho, V: Vipos, VM: Villa Montes, Y: Yaquiasme.

TpsDig2 v. 2.31 program (Rohlf, 2017a). Only nine landmarks were selected since they were sufficient to describe the general shape and features of the shell (Fig. 1). The configuration of the landmarks was translated, standardised to centroid size $=1$ and aligned to produce a consensus configuration through the General Procrustes Analysis (GPA) with the TpsRelw program v. 1.69 (Rohlf, 2017b).

An exploratory relative warp analysis (RW) - also known as Principal Component Analysis on the residuals from superimposition- was performed initially to assess if the relationships between shapes and variations in shell shape were visualized with thin-plate spline deformation grids with TpsRewl. On the other hand, we utilized 80 specimens from nine different locations in Bolivia and Argentina for the geometric morphometric analysis: Cabra Corral dam (7) (830 m), La Candelaria (9) (970 $\mathrm{m})$, Yaquiasme (6) (760 m), Juramento river (10) (800 m), Cerro Colorado (11) (450 m), Embarcación in Salta Province (10) $(260 \mathrm{~m})$, Vipos (10) $(850 \mathrm{~m})$, Ticucho (10) $(750 \mathrm{~m})$ (Tucuman Prov.) and Villa Montes in Bolivia's Tarija Department (440 m) (7) (Fig. 2).

Statistical analysis: Multivariate Analysis of Variance (MANOVA) was run with Infostat v. 2016 (Di Rienzo et al., 2016) on the scores of each specimen on the first relative warps, to test for significant differences among groups formed. 


\section{RESULTS}

Shell: It is medium to large, fusiform (Fig. 3A, Fig. 3E, Fig. 3F, Fig. 3G) to elongate-ovate (Fig. 3B, Fig. 3D, Fig. 3H), with thick walls, 7.25-8.5 flat to slightly convex whorls, conic spire and body whorl $50-65 \%$ of its full length (Fig. 3A, Fig. 3B, Fig. 3C, Fig. 3D, Fig. 3E, Fig. 3F, Fig. 3G, Fig. $3 \mathrm{H}$ ). The protoconch is dark to pure black in some specimens (Fig. 3B, Fig. 3E), with very thin axial shallow ribs, few elevated, parallels each to other and thin grooves closely spaced crossing them. The teleoconch is opaque, pale yellow to whitish, with dark to light brown axial bands, purple and blue in some specimens. The axial bands have defined (Fig. 4A, Fig. 4B, Fig. 4G, Fig. $4 \mathrm{~L}$ ) or diffuse edges (Fig. 4C, Fig. 4D, Fig. 4E, Fig. 4F, Fig. 4H, Fig. 4K), some specimens have whitish spiral bands (Fig. 4C, Fig. 4E, Fig. 4H, Fig. 4I, Fig. 4J, Fig. 4K).

The teleoconch has axial straight oblique growth lines regularly arranged or axial pronounced costules densely arranged which gives a rough appearance to the shell. It has a brown color with whitish spiral bands or brown spots irregularly arranged. It also can a have axial straight oblique growth lines irregularly arranged. There is a slightly deep suture (Fig. 3A, Fig. 3B, Fig. 3C, Fig. 3D, Fig. 3E, Fig. 3F, Fig. 3G, Fig. 3H). The aperture is from elongate-ovate (Fig. 3A, Fig. 3E, Fig. 3F, Fig. $3 \mathrm{G}$ ) to ovate (Fig. 3B, Fig. 3C, Fig. 3D, Fig. $3 \mathrm{H})$, narrow, wide and tall, $35-40 \%$ of the shell length (Fig. 3). The parietal space is narrow to wide, with parietal callus in some specimens (Fig. 3D). The peristome is simple and sharp. The umbilicus is rimate to narrow, surrounded by dark brown band in some specimens.

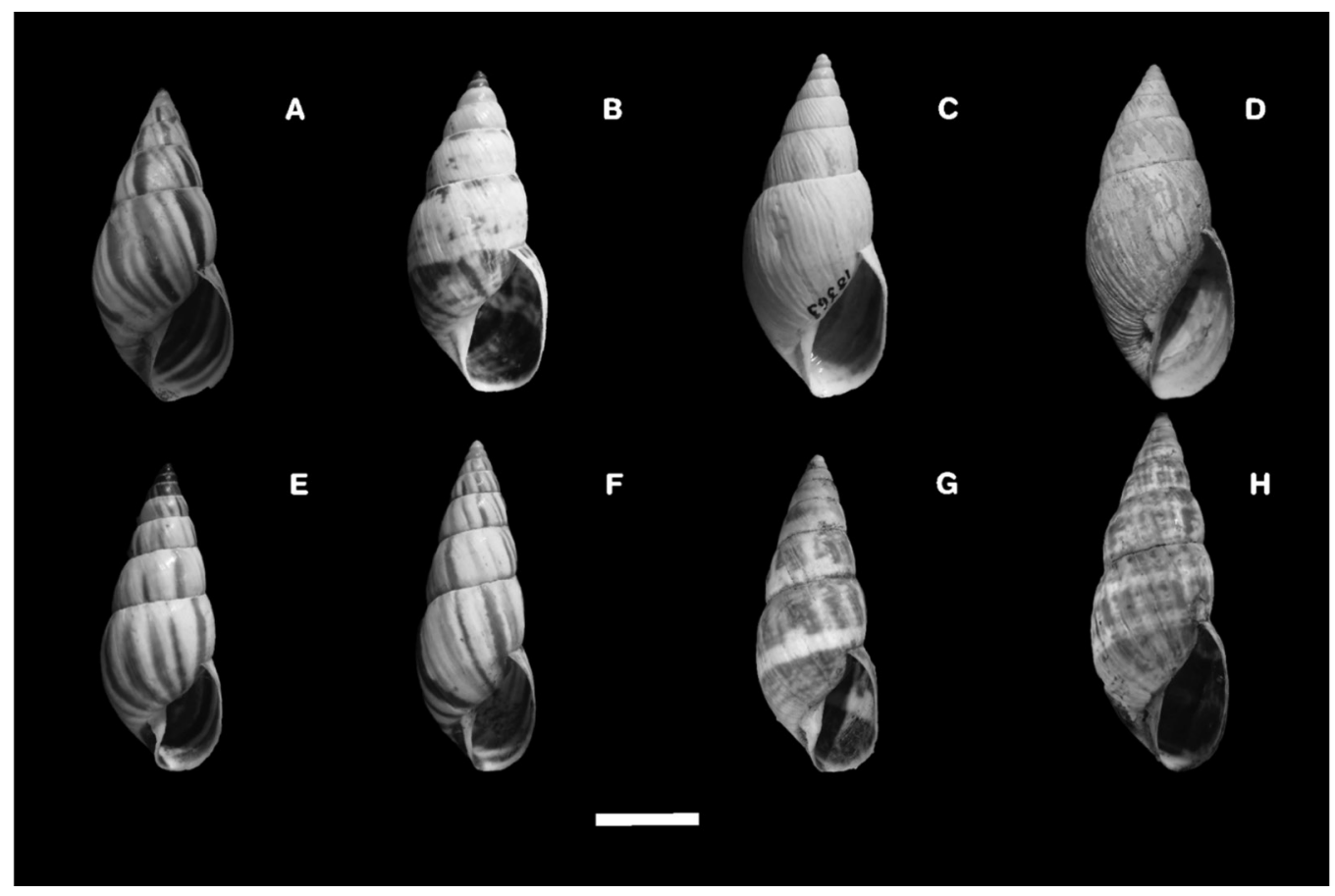

Fig. 3. Shell morphology per species: (A) Bostryx torallyi. (B) Bulimulus (M.) climacographus (Holotype). (C) Peronaeus (L.) torallyi corrugatus (Holotype). (D) Peronaeus (L.) torallyi avus (Holotype). (E) B. nigroumbilicatus (Holotype). (F) B. nigroumbilicatus (Paratype). (G) Peronaeus birabeni (Holotype). (H) P. birabeni. Scale bar $=10 \mathrm{~mm}$.

Fig. 3. Morfología de la concha según la especie: (A) Bostryx torallyi. (B) Bulimulus (M.) climacographus (Holotype). (C) Peronaeus (L.) torallyi corrugatus (Holotype). (D) Peronaeus (L.) torallyi avus (Holotipo). (E) B. nigroumbilicatus (Holotipo). (F) B. nigroumbilicatus (Paratipo). (G) Peronaeus birabeni (Holotipo). (H) P. birabeni. Barra de escala $=10 \mathrm{~mm}$. 

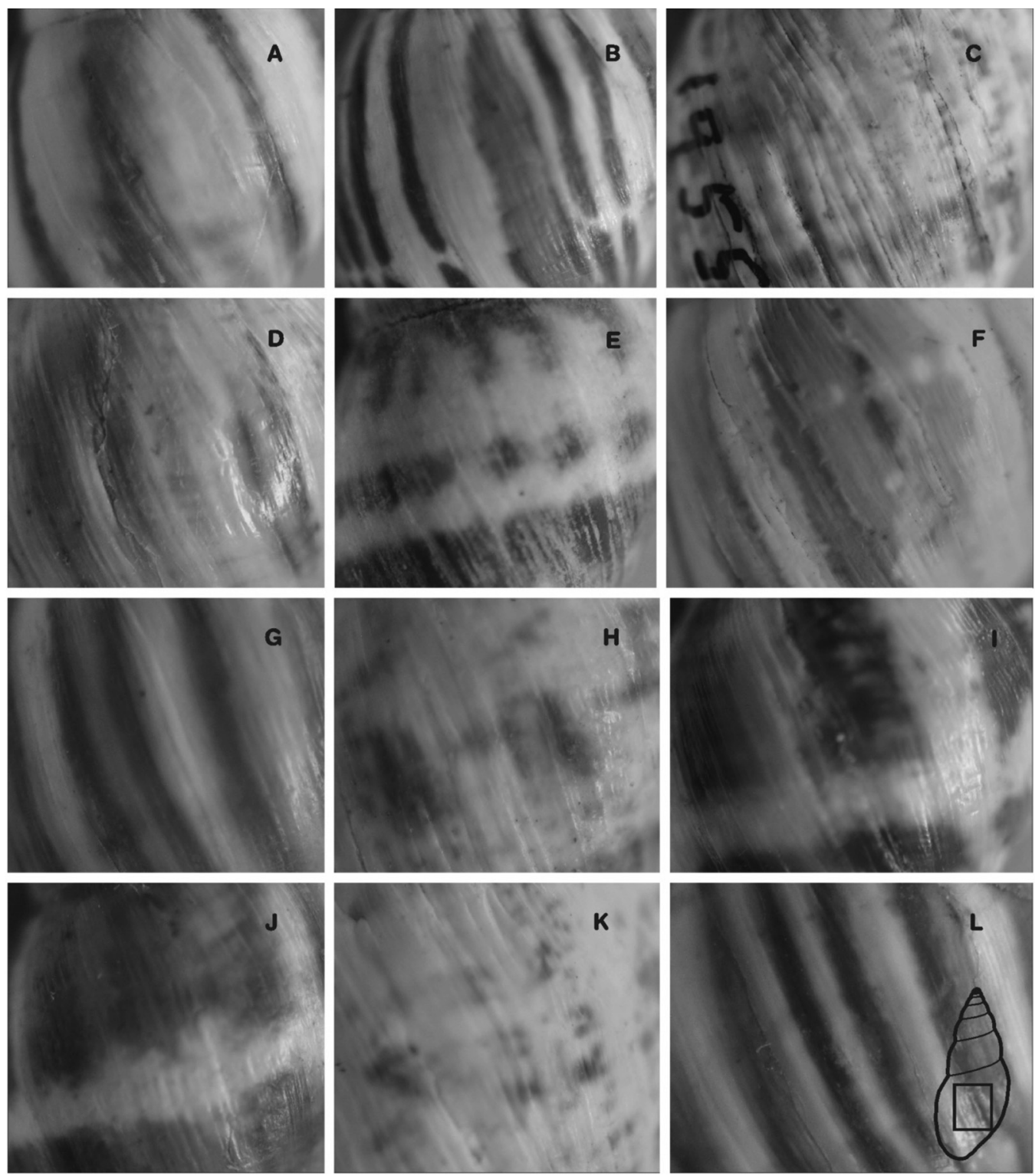

Fig. 4. Dorsal view of the teleoconch banding patterns from the following localities: (A, E) Ticucho, (B, D) Vipos, (C) Juramento river, (F) Cabra Corral dam, (G) Villa Montes, (H) Cerro Colorado, (I) Embarcación. In the lower shell scheme, the full dorsal view is shown. Scale bar $=10 \mathrm{~mm}$.

Fig. 4. Vista dorsal del patrón de bandas de la teleoconcha en las siguientes localidades: (A, E) Ticucho, (B, D) Vipos, (C) Río Juramento, (F) Represa Cabra Corral, (G) Villa Montes, (H) Cerro Colorado, (I) Embarcación. En el esquema inferior de la concha, se muestra la vista dorsal completa. Barra de escala $=10 \mathrm{~mm}$. 

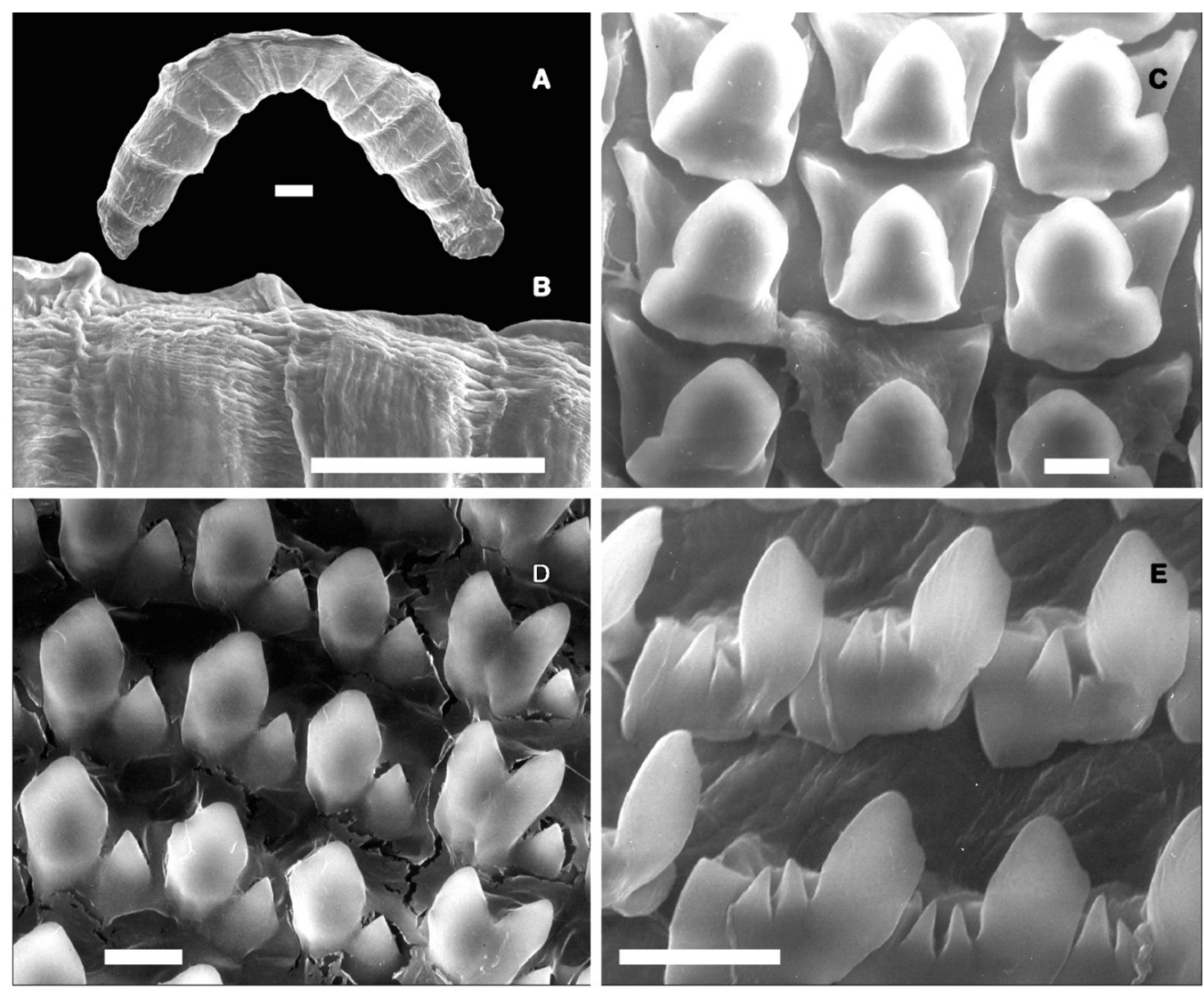

Fig. 5. Jaw (A) General view (scale bar: $100 \mu$ ). (B) Detail of sculpture of the jaw consisting of transverse striae and axial shallow ribs (sb: $320 \mu$ ). Radula (C) Central unicuspid tooth and first lateral unicuspid teeth (sb: $1000 \mu$ ). (D) Lateral bicuspid teeth (acute mesocone and deltoid ectocones) (sb: $1200 \mu)$. (E) Marginal teeth (bicuspid, serrated ectocones) (sb: $1500 \mu)$.

Fig. 5. Mandíbula (A) vista general (barra de escala: $100 \mu$ ). (B) Detalle de la escultura de la mandíbula con estrías transversas y cóstulas axiales (bs: $320 \mu$ ). Rádula (C) Diente central unicúspide y primeros dientes laterales unicúspides (bs: $1000 \mu$ ). (D) Dientes laterales bicúspides (mesocono agudo y ectoconos deltoides) (bs: $1200 \mu$ ). (E) Dientes marginales (bicúspides, ectoconos serrados) (bs: $1500 \mu$ ).

Jaw: It is arched with a central triangular plate and 14-15 lateral rectangular plates separated by grooves. The sculpture consists of transverse striae and axial shallow ribs (Fig. 5A, Fig. 5B).

Radula: The central tooth is triangular, unicuspid, with a pointed end (Fig. 5B). The first lateral tooth is unicuspid, bigger than the central (Fig. 5B), the others are bicuspid (acute mesocone and deltoid ectocone) with a broad basal plate (Fig. 5C). Marginal teeth are bicuspid, serrated ectocones divided into small cones (Fig. 5D).

Reproductive System: The ovotestis is embedded in the digestive gland. Its hermaphroditic duct has a central portion, the vesicle seminalis is thickened and convoluted (Fig. 6A). The distal portion of the hermaphroditic duct ending is at the albumen gland, inserted into the half portion and fertilization pouch-spermathecal complex (Fig. 6A). The fertilization pouch-spermathecal complex is 


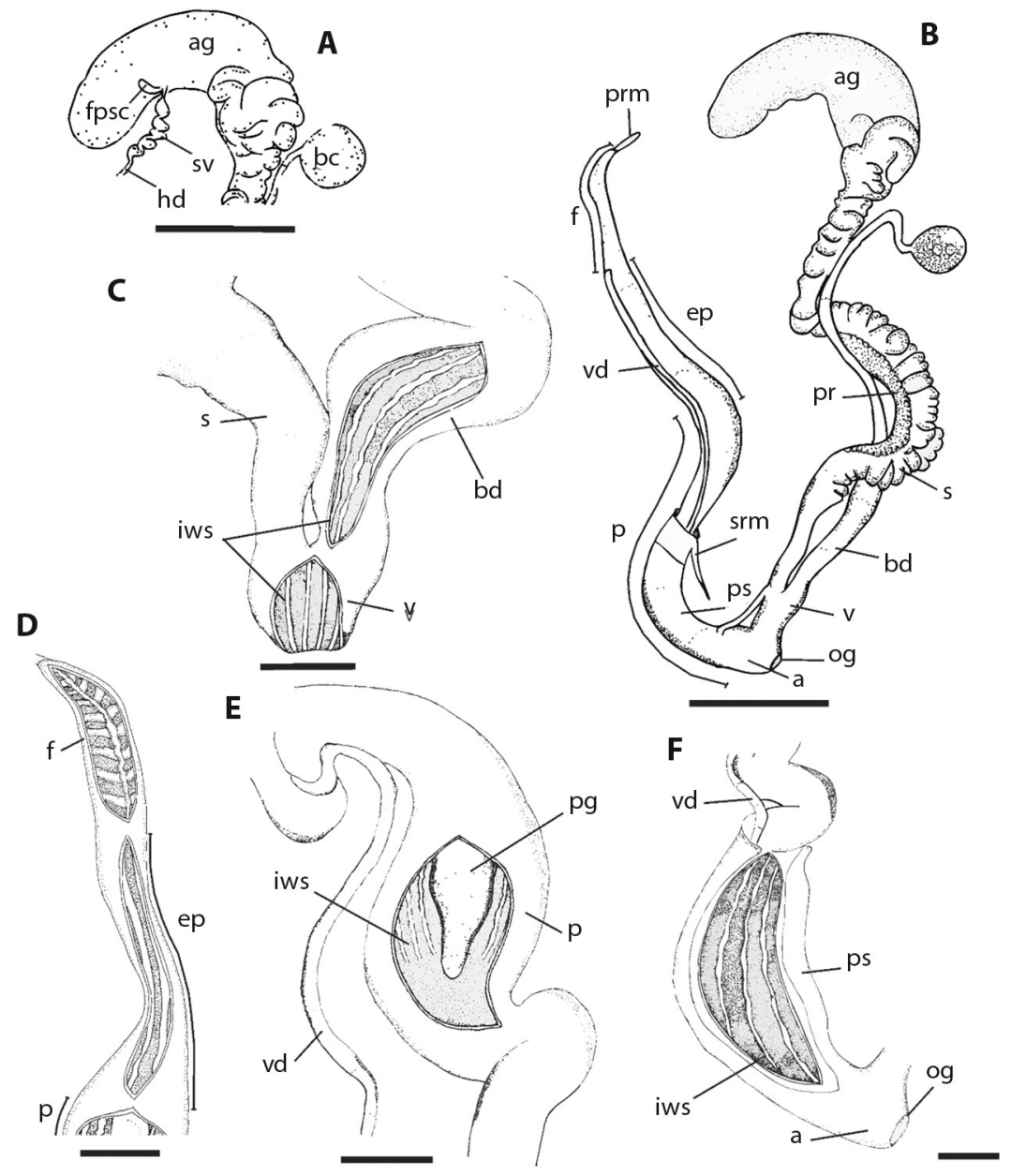

Fig. 6. Reproductive system (A) Detail of fertilization pouch-spermathecal complex (scale bar: $5 \mathrm{~mm}$ ). (B) General view (sb: $5 \mathrm{~mm}$ ). Inner wall sculpture of: (C) Bursa copulatrix duct and vagina (sb: $1 \mathrm{~mm}$ ). (D) Flagellum and epiphallus (sb: $1 \mathrm{~mm}$ ). (E) Proximal portion of penis (sb: $1 \mathrm{~mm})$. (F) Distal portion of penis $(\mathrm{sb}: 1 \mathrm{~mm})$. Abbreviations: $\mathrm{a}=\mathrm{atrium}, \mathrm{ag}=$ albumen gland, $b c=$ bursa copulatrix, $b d=$ bursa copulatrix duct, ep $=$ epiphallus; $f=$ flagellum, fpsc $=$ fertilization pouchspermathecal complex, hd = hermaphroditic duct, iws $=$ inner wall sculpture, $o g=$ opening genital, $p=p e n i s, p g=p e n i s$ gland, $\mathrm{pr}=$ prostate, $\mathrm{prm}=$ penial retractor muscle, $\mathrm{ps}=$ penial sheath, $\mathrm{s}=$ spermoviduct, $\mathrm{srm}=$ sheath retractor muscle, $\mathrm{sv}$ $=$ seminal vesicle, $\mathrm{v}=$ vagina, $\mathrm{vd}=$ vas deferens.

Fig. 6. Sistema reproductor (A) Detalle del complejo bolsa de fertilización-espermateca (barra de escala: $5 \mathrm{~mm}$ ). (B) Vista general (bs: $5 \mathrm{~mm}$ ). Escultura de la pared interna de: (C) Conducto de la bursa copulatrix y vagina (bs: $1 \mathrm{~mm}$ ). (D) Flagelo y epifalo (bs: $1 \mathrm{~mm}$ ). (E) Porción proximal del pene (bs: $1 \mathrm{~mm}$ ). (F) Porción distal del pene (bs: $1 \mathrm{~mm}$ ). Abreviaturas: a = atrio, ag = glándula del albumen, $\mathrm{bc}=$ bursa copulatrix, $\mathrm{bd}=$ conducto de la bursa copulatrix, ep $=$ epifalo, $\mathrm{f}=$ flagelo, fpsc $=$ complejo bolsa de fertilización-espermateca, $h d=$ conducto hermaphrodita, iws $=$ escultura de la pared interna, $\mathrm{og}$ $=$ abertura genital, $\mathrm{p}=$ pene, $\mathrm{pg}=$ glándula peneal, $\mathrm{pr}=$ próstata, $\mathrm{prm}=$ músculo retractor del pene, $\mathrm{ps}=$ vaina peneal, $\mathrm{s}=$ espermoviducto, $\mathrm{srm}=$ músculo retractor de la vaina, $\mathrm{sv}=$ vesícula seminal, $\mathrm{v}=$ vagina, $\mathrm{vd}=$ vaso deferente. 
finger-shaped (Fig. 6A), while the albumen gland is bean shaped (Fig. 6A, Fig. 6B). The proximal portion of the sperm-oviduct is enlarged over the albumen gland (Fig. 6B). The oviductal portion of the sperm-oviduct is organized into transversal folds. The bursa copulatrix duct has a round bursa copulatrix sac, reaching the distal portion of the albumen gland (Fig. 6B). It widens at the distal portion and has an inner wall with longitudinal zigzag folds (Fig. 6B, Fig. 6C).

The vagina is cylindrical, one fourth of the penis length. The inner wall has longitudinal straight folds (Fig. 6B, Fig. 6C). The penial retractor muscle is terminally inserted in the flagellum (Fig. 6B). It also has inner diagonal folds and a central longitudinal fold (Fig. 6D). On one hand, the epiphallus' length is $2 / 3$ of the penis length, progressively increasing its width towards the penis (Fig. 6B). It has an inner wall in the proximal portion with longitudinal straight folds followed by zigzag folds in the distal portion (Fig. 6D). On the other hand, the proximal portion of the penis is as wide as the distal portion of the epiphallus, progressively decreasing its diameter toward the distal portion. Its inner wall also has longitudinal relaxed zigzag folds followed by a smooth area (Fig. 6E).

The penis gland is triangular, free to the penis inner wall in the distal portion, reaching to the beginning of distal portion of penis (Fig. $6 \mathrm{E})$. Its distal portion is tubular towards the atrium, with uniform diameter and an inner wall with longitudinal thin relaxed zigzag folds (Fig. 6F). The penis sheath covers the distal portion with the retractor muscle inserted in proximal end (Fig. 6B). The vas deferens is inserted in the distal portion of penial sheath, emerging at the proximal portion and running parallel to the penis and epiphallus. It ends in the epiphallus-flagellum boundary (Fig. 6B). The atrium is short, with inner longitudinal zigzag folds (Fig. 6B).

Geometric morphometric analysis: There was a clear difference among localities. The scatter plot shows two clusters along relative warp 1 (rw1) (60.87 \%) (Fig. 7). The deformation grids describe deviations from the standard form along the relative warps axes, showing the main differences between localities. Positive rw1 scores indicate the presence of elongate-ovate shells with conic and short spire, rounded body whorl and an ovate aperture, represented by specimens from Vipos, Juramento River, Cabra Corral dam, La Candelaria and Yaquiasme. On the other hand, specimens from Cerro Colorado, Embarcación and Villa Montes have negative rw1 scores. They had a fusiform shell and a thin, very acute spire, thinner body whorl and elongate aperture. On the rw2 (10.31\%), high scores indicate an elongated body whorl and aperture, represented by specimens from Cerro Colorado, Villa Montes, Vipos, La Candelaria and Yaquiasme. Low scores with opposite characteristics were represented by specimens from Cabra Corral, Juramento River and Embarcación. Specimens from Ticucho showed a high variability in shell shape. The MANOVA test showed that the first seven relative warps $(94.62 \%)$ of the specimens indicated statistically significant differences $(\lambda=0.03 ; \mathrm{P}<0.0001)$.

\section{DISCUSSION}

Since the original description of $B$. toral$l y i$, the presence of chromatic variability within this species has been described. Some specimens have shown whitish colors and longitudinal bands of different colors, transverse stains or even dark protoconch. With respect to the species synonymized with $B$. torallyi by Miquel (1995), the original morphological descriptions of $B$. nigroumbilicatus Preston, 1907, B. climacographus Holmberg, 1912 and P. birabeni Hylton Scott, 1948, are very similar. They only vary in details such as presence or absence of a darker band in the region of the umbilicus or the presence of white spiral bands crossing darker axial bands. According to Hylton Scott (1948), P. birabeni and B. climacographus have a remarkable similarity in band pattern and they only differ the aperture length: B. climacographus' is longer. 

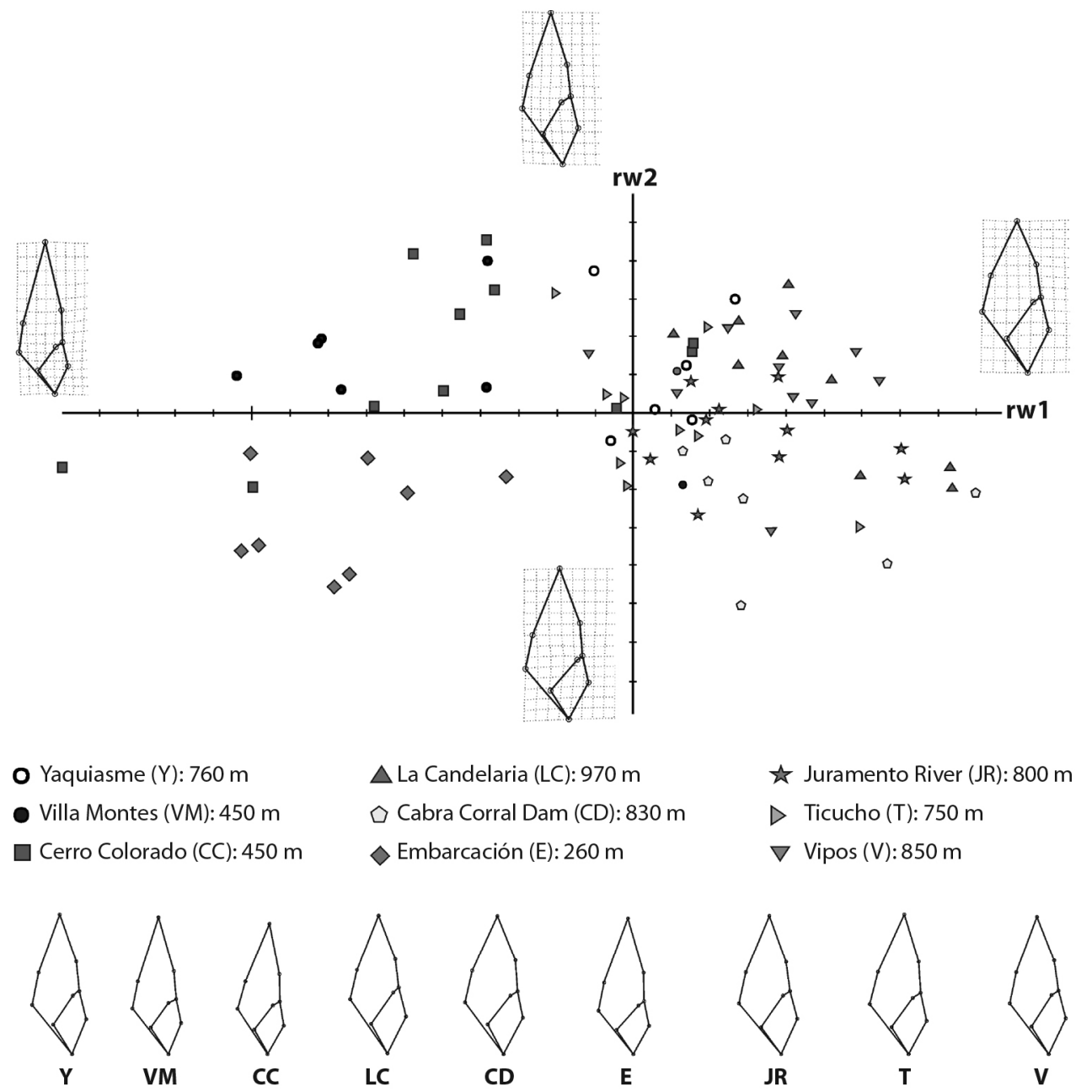

Fig. 7. Scatter plot of the first and second relative warp scores of shell shape specimens. The grids show shape changes along relative warp 1 and 2 of specimens.

Fig. 7. Diagrama de dispersión de las puntuaciones del primer y segundo "relative warps" de la forma de la concha de los especímenes. Las grillas muestran los cambios de forma de estos a lo largo de los "relative warps" 1 y 2.

Additionally, when Parodiz (1947) described Bostryx torallyi avus, B. torallyi corrugatus and $B$. torallyi nigroumbilicatus and considered Bulimus draparnaudi Pfeiffer, 1846 as a subspecies of $B$. torallyi, he highlighted their resemblance. Later on, certain characters were identified as diagnostic to Argentinian species of the genus such as the protoconch sculpture, penis shape and internal sculpture of the phallic complex (Miranda, 2016) in $B$. torallyi. This confirmed its correct systematic position. When comparing its shells of Bostryx species in Argentina, characters such as type of umbilicus, suture and peristome are constant in all those species as well as the reproductive system have little variability (Miranda, 2016). For these reasons, the synonymies proposed by Miquel (1995) and Cuezzo et al. (2013) were maintained in the present work since they can be anatomically justified.

In this study, numerous lots and type material of species were examined. The color 
and banding patterns varied greatly among these organisms. In particular, the polychromatic shell and the banding pattern were common in terrestrial gastropods of families such as Helicidae, Bradybaenidae, Partulidae and Achatinnidae (Backeljau, Baur, \& Baur, 2001). This polychromy has been thoroughly studied and attributed to a number of factors: genetic control, habitat heterogeneity, type of habitat (open or shaded), and amount of solar energy received by a snail and natural selection by predators (Ozgo, 2004; Surmacki, OzarowskaNowicka, \& Rosin, 2007; Cameron \& Pokryszko, 2008). In our case, the $B$. torallyi specimens from the same location varied in coloration and banding pattern. These banding patterns were observed in specimens from other localities. Therefore, it was determined that the variation in coloration of this species is independent of large-scale factors such as topography, climatic conditions or vegetation.

On the other hand, the geometric morphometric analysis allowed a more thorough study of the shell shape variation. For instance, it established that specimens from different localities had a pronounced intraspecific polymorphism of shell shape in a small geographical area. Particularly, the general shell shape of specimens from Embarcación, Villa Montes and Cerro Colorado were similar. According to Hylton Scott (1948), Cerro Colorado hosts a big number of land snails with special characters resulting in clearly differentiated local forms, such as Clessinia pyriformis (Pilsbry, 1901), C. dubia Hylton Scott (1948) and Bulimulus gracilis (Hylton Scott, 1948). This fact was corroborated in the present study where specimens from Cerro Colorado possessed a thinner general shell shape and aperture. Within the organisms collected in the Cabra Corral dam, Juramento river, Yaquiasme and Ticucho, the ones in the first two locations (which are very near) where the most similar. Similarly, specimens from Yaquiasme and Ticucho were quite similar, but gastropods from Ticucho presented a thinner body whorl. Regarding internal anatomy, no morphological differences were found between specimens from different localities.
Land snails are sensitive to environmental conditions and several studies have shown that interaction with the environment affects their shell's characteristics (Chiba, 2004; CarvajalRodríguez et al., 2005; Signorelli, Márquez, \& Pastorino, 2012). In the current study, it seems altitude is a factor than can determine morphometric differences. This association has been demonstrated in several other studies. For example, in Arianta (Helicidae), Haase, Esch \& Misof (2013) found clear morphological differences in shell shape where specimens from lowlands had higher spires, whereas highlands hosted lower spire populations. Similarly, specimens from lower localities (260-450 m), such as Villa Montes, Cerro Colorado and Embarcación, showed a higher spire compared with specimens from higher localities (750-970 m). A relationship between variations in shell shape and altitude could suggest that morphological variability in $B$. torallyi is a result of adaptation to the environment. Therefore, it would be important to include specimens from the entire distribution area to further study the relationship between the shell shape and altitude in order to assess whether the current conclusions are on the right track.

In conclusion, as evidenced, the sculpture of the protoconch and anatomy of $B$. torally $i$ coincided with the other Argentinian species of the genus. Additionally, it was shown that the landmark-based geometric morphometric analysis of shell shape is a useful tool for exploring intraspecific differences. In future morphological studies, it could complement the traditional qualitative description of the shell in gastropods.

Ethical statement: the author declares that she agrees with this publication; that there is no conflict of interest of any kind; and that she followed all pertinent ethical and legal procedures and requirements. All financial sources are fully and clearly stated in the acknowledgements section. A signed document has been filed in the journal archives. 


\section{ACKNOWLEDGMENTS}

I would like to thank the curators of the malacological collections consulted: E. Salas Oroño (IFML-Moll), A. Tablado (MACN-In) and G. Darrigran (MLP) for their assistance and supply of material. I would also like to thank M. G. Cuezzo for her helpful comments on the manuscript.

\section{RESUMEN}

\section{Anatomía y variabilidad de la forma de la concha en el caracol terrestre Bostryx torallyi (Stylomma-} tophora: Bulimulidae). Introducción: El gasterópodo Bostryx torallyi exhibe una gran variabilidad en la forma y coloración de su concha. Subespecies de este organismo han sido descritas con base en los caracteres de la concha; pero, dadas las sutiles diferencias, fueron luego sinonimizadas. Hasta el momento, la variabilidad de la concha ha sido analizada solo descriptivamente y su anatomía es aún desconocida. Objetivo: En este estudio, los objetivos fueron: proveer información anatómica de $B$. torallyi y usar un análisis de morfometría geométrica para evaluar la variación de la forma de la concha entre especímenes. Métodos: Para ello, se examinó y disectó material tipo y numerosos lotes. Adicionalmente, se realizaron análisis del "relative warp", basados en nueve "landmarks" en vista ventral de la concha, empleando 80 especímenes de nueve localidades de Bolivia y Argentina. Resultados: De acuerdo con los resultados, la morfometría geométrica resultó útil para demostrar diferencias en forma de la concha entre localidades; por ejemplo, se detectaron diferencias evidentes entre localidades de alta y baja altitud. Se determinó que la variación en la coloración de esta especie es independiente de factores a gran escala, dado que los especímenes examinados proceden de ambientes con condiciones similares. Por otro lado, la escultura de la protoconcha y la anatomía de B. torallyi resultaron coincidentes con la de otras especies de este género recolectadas en Argentina. Conclusiones: Se concluyó que el análisis de morfometría geométrica de la forma de la concha fue un buen complemento a la descripción cualitativa tradicional de caracteres de concha.

Palabras clave: altitud, variabilidad intraspecífica, morfometría geométrica, deformación relativa, Argentina, Bolivia.

\section{REFERENCES}

Backeljau, T., Baur, A., \& Baur, B. (2001). Population and Conservation Genetics. In G. M. Barker (Ed.), The biology of terrestrial Molluscs (pp. 383-412). Wallingford, United Kingdom: CABI Publishing.
Cameron, R. A. D., \& Pokryszko, B. M. (2008). Variation in Cepaea populations over 42 years: climate fluctuations destroy a topographical relationship of morph-frequencies. Biological Journal of the Linnean Society, 95, 53-61.

Carvajal-Rodríguez, A., Conde-Padin, P., \& Rolan-Álvarez, E. (2005). Decomposing shell form into size and shape by geometric morphometric methods in two sympatric ecotypes of Littorina saxatilis. Journal of Molluscan Studies, 71, 313-318.

Chiba, S. (2004). Ecological and morphological patterns in communities of land snails of the genus Mandarina from the Bonin Islands. Journal of Evolution Biology, 17, 131-143.

Cuezzo, M. G., Miranda, M. J., \& Ovando, X. M. C. (2013). Species catalogue of Orthalicoidea in Argentina (Gastropoda: Stylommatophora). Malacologia, $56,135-191$.

Dillon, R. T., \& Jacquemin, S. J. (2015). The Heritability of Shell Morphometrics in the Freshwater Pulmonate Gastropod Physa. PLoS ONE, 10(4), e0121962. DOI: https://doi.org/10.1371/journal.pone.0121962

Di Rienzo, J. A., Casanoves, F., Balzarini, M. G., González, L., Tablada, M., \& Robledo, C. W. (2016). InfoStat (Version 2016). Retrieved from https://www.infostat. com.ar/

Haase, M., Esch, S., \& Misof, B. (2013). Local adaptation, refugial isolation and secondary contact of alpine populations of the land snail Arianta arbustorum. Journal of Molluscan Studies, 79, 241-248.

Hylton-Scott, M. I. (1948). Moluscos del biotopo del Cerro Colorado (Salta). Acta Zoológica Lilloana, 6, 229-239.

Márquez, F., \& van der Molen, S. (2011). Intraspecific shell-shape variation in the razor clam Ensis macha along the Patagonian coast. Journal of Molluscan Studies, 77(2), 123-128.

Miquel, S. E. (1995). Las especies del género Bostryx Troschel, 1847 en la República Argentina (2da. y última parte) (Gastropoda: Stylommatophora: Bulimulidae). Archiv für Molluskenkunde, 124, 119-127.

Miranda, M. J. (2016). Cladistic analysis of the Argentinian species of the genus Bostryx (Gastropoda, Stylommatophora) based on morphological evidence. Papeis Avulsos de Zoologia, 56(10), 109-133.

Miranda, M. J., \& Cuezzo, M. G. (2014). Taxonomic revision of Bostryx stelzneri species complex, with description of a new species (Gastropoda: Orthalicoidea: Bulimulidae). American Malacolological Bulletin, 32(1), 74-93. 
Ozgo, M. (2004). Cepaea nemoralis (L.) in Southeastern Poland: Association of morpho frequencies with habitat. Journal of Molluscan Studies, 71, 93-103.

Parodiz, J. J. (1947). Contribuciones al conocimiento de los moluscos terrestres Sudamericanos, 5. Comunicaciones Zoológicas del Museo Historia Natural de Montevideo, 2, 1-32.

Pfenninger, M., \& Magnin, F. (2001). Phenotypic evolution and hidden speciation in Candidula unifasciata ssp. (Helicellinae, Gastropoda) inferred by $16 \mathrm{~s}$ variation and quantitative shell traits. Molecular Ecology, 10, 2541-2554

Pilsbry, H. A. (1901). Manual of Conchology, Pulmonata ( ${ }^{\mathrm{a}}$ serie). Philadelphia, United States: Palala Press.

Ploeger, S., \& Breure, A. S. H. (1977). A rapid procedure for preparation of radulae for routine research with the scanning electron microscope. Basteria, 41 , $47-52$.

Quintana, M. (1982). Catálogo preliminar de la malacofauna del Paraguay. Revista Museo Argentino de Ciencias Naturales, Zoología, 11, 61-158.

Ramírez, R., Paredes, C., \& Arenas, J. (2003). Moluscos del Perú. Revista de Biología Tropical, 51, 225-284.
Rohlf, F. J. (2017a). TpsDig (Version 2.31). Retrieved from https://life.bio.sunysb.edu/morph/soft-dataacq.html

Rohlf, F. J. (2017b). TpsRewl (Version 1.69). Retrieved from https://life.bio.sunysb.edu/morph

Rohlf, F. J. (2019). TpsUtil (Version 1.78). Retrieved from https://life.bio.sunysb.edu/morph/

Signorelli, J. H., Márquez, F., \& Pastorino, G. (2012). Phenotypic variation of south-western Atlantic clam Mactra isabelleana (Bivalvia: Mactridae). Journal of the Marine Biological Association of the United Kingdom, 93(2), 1-7.

Smith, U. E., \& Hendricks, J. R. (2013). Geometric Morphometric Character Suites as Phylogenetic Data: Extracting Phylogenetic Signal from Gastropod Shells. Systematic Biology, 62(3), 366-385.

Surmacki, A., Ozarowska-Nowicka, A., \& Rosin, Z. M. (2007). Color polymorphism in a land snail Cepaea nemoralis (Pulmonata: Helicidae) as viewed by potential avian predators. Naturwissenschaften, 100, 533-540.

Zischka, R. (1953). Catálogo de las conchas y caracoles bolivianos. Folia Universitaria, 10, 69-85. 